\title{
PENGARUH SILENT READING TERHADAP PENINGKATAN KECERDASAN KOGNITIF PESERTA DIDIK
}

\author{
Sufinatin Aisida \\ Fakultas Agama Islam Universitas Sunan Giri Surabaya \\ Email:Sufi50928@gmail.com
}

\begin{abstract}
Reading habits must become a culture, especially ini educational institutional such as schools, the reading habits has been determined by the goverment in accordance with UU RI Nomor 20 pasal 4 ayat 5 tahun 2003 about the national education system. Many factors affect the level of cognitive intelligence of students, one of wich is silent reading. Reading this silent make it easier for students to understand the knowledge they get from books and teacher information, one of the schools that has implemented silent training is YPM Junior High School, this silent reading activity provides a special time for silent reading before starting lessons. As for the objectivites to be achieved in this study are: 1) to find out about silent reading activities at YPM Taman Sidoarjo High School, 2) to find out the level of cognitive intelligence of students in akidah akhlak subjects at SMK YPM 3 Sidoarjo, 3) to find the effect of the implementation of silent reading on the level of cognitive intelligence of students at SMA YPM 3 Sidoarjo.

This research is a quantitative. As for the data collection techniques using documentation and questionnaires. Data analysis using teh percentage and correlation of the production moment. The result is 1). Implementation of reading a razor blade in SMK YPM 3 Taman Sidoarjo otherwise good enough, because it is in the range of 56-75\% this is based on the percentage results with a value of $71 \% 2$ ) the level of cognitive intelligence of students at SMA YPM 3 Taman Sidoarjo is in the range of $56-75 \%$ this based on the percentage results with a value of $68 \%$. Wich is ontherwise good enough. 3). Silent reading gives $34,3 \%$ influence on the level of cognitive intelligence of student in the subject of akidah akhlak, in this case it means that $34.3 \%$ of students area able to think, assess, state, expalain and provide examples of subject matter and $65.7 \%$ is influenced by other factors that have not been studied by researchers.
\end{abstract}

Keywords: Silent reading, Cognitive intelligence. 
Sufinatin Aisida, Pengaruh Silent Reading Terhadap Peningkatan Kecerdasan Kognitif Peserta Didik

\section{Pendahuluan}

Pendidikan adalah upaya sadar dan terencana untuk mendapatkan sejumlah informasi dan ilmu pengetahuan demi memperbaiki kualitas sumber daya manusia yang pada akhirnya dapat berguna bagi dirinya sendiri maupun bagi masyarakat secara umum dan sebagai bangsa secara menyeluruh. Salah satu kegiatan dalam pendidikan adalah tidak terlepas dari adanya kegiatan kalistung (membaca, menulis dan berhitung). Seperti yang tertuang dalam UU RI ${ }^{1}$ Nomor 20 Pasal 4 ayat 5 tahun 2003 tentang Sistem Pendidikan Nasional menyebutkan bahwa "Pendidikan diselenggarakan dengan mengembangkan budaya minat baca, menulis, dan berhitung bagi segenap warga masyarakat.

Sedangkan menurut Tilaar yaitu, membaca sesungguhnya adalah fondasi dari proses belajar. Masyarakat belajar karena membangun perilaku dan budaya membaca adalah kunci untuk membangun masyarakat ilmu pengetahuan yang berbasis pada pengembangan kualitas sumber daya alam. ${ }^{2}$

Menurut Graff dalam Sugihartati ${ }^{3}$ yaitu reading of silent adalah aktivitas membaca interpretatife, hermeunetik, yang dibentuk oleh ekspektasi dan pengalaman membaca serta konteks sosial-budaya yang melingkupinya. Agar dapat membaca senyap dengan baik, siswa perlu membiasakan diri untuk melakukan kegiatan ini. Latihan membaca senyap atau membaca dalam hati harus dimulai ketika anak sudah dapat membaca sendiri. Membaca senyap sangatlah penting karena keterampilan ini merupakan kunci bagi semua ilmu pengetahuan ${ }^{4}$

Mengingat pentingnya membaca senyap (silent reading), sesuai dengan Permendikbud Nomor 23 Tahun 2015 tentang Pertumbuhan Budi Pekerti yang terdapat pada lampiran, pemerintah mewajibkan sekolah-sekolah menggunakan waktu 15 menit sebelum pembelajaran untuk membaca buku selain buku mata

\footnotetext{
${ }^{1}$ UU RI, Nomor 20 Pasal 4 ayat 5 tahun 2003 tentang Sistem Pendidikan Nasional

2 Tilaar, H.A.R., Perubahan dan Pendidikan Pengantar Pedagogik Transformasi Untuk Indonesia, (Jakarta, Pt. Grasindo, 2002), hIm. 382

${ }^{3}$ Sugiartini, Membaca Gaya Hidup dan Kapitalisme, (Jakarta, Alfabeta, 2010), hlm.4

4 Tarigan, Henry Guntur. Membaca sebagai Suatu Keterampilan Berbahasa. (Bandung, Remaja Rosdakarya, 2008). hIm.30
} 
Sufinatin Aisida, Pengaruh Silent Reading Terhadap Peningkatan Kecerdasan Kognitif Peserta Didik

pelajaran setiap hari. Pemilihan jenis membaca yang diterapkan menjadi tugas sekolah disesuaikan dengan kondisi siswa masing-masing. Jenis membaca senyap (silent reading) merupakan salah satu jenis membaca yang pantas untuk diterapkan. Namun, belum banyak sekolah yang memberikan waktu khusus untuk membaca senyap (silent reading) sebelum memulai mata pelajaran. Berbeda dengan sekolah lain, SMK YPM 3 Taman menjadi salah satu sekolah yang memberikan waktu khusus bagi siswanya untuk membaca senyap (silent reading) sebelum memulai pelajaran.

SMK YPM 3 Taman Sidoarjo terletak di jalan Raya Ngelom 86-B kelurahan Ngelom, kecamatan Taman, Kabupaten Sidoarjo, SMK YPM 3 Taman, Sidoarjo didirikan sejak 25 Juli 1990 dan operasionalnya pada tahun 1991, pada tahun pelajaran 2019/2020 SMK YPM 3 Taman Sidoarjo memiliki 3 (tiga) program keahlian yaitu jurusan Administrasi Perkantoran, Akutansi dan Multimedia dengan status "Terakreditasi A" Peserta didik SMK YPM 3 Taman pada tahun pelajaran 2019/2020 berjumlah 1.204. kelas X berjumlah 395 peserta didik. Kelas XI berjumlah 411 peserta didik. Kelas XII berjumlah 398 peserta didik.

Dengan jumlah siswa yang lumayan banyak ini serta membudayakan gemar membaca maka SMA YPM 3 Taman Sidoarjo ini melaksanakan silent reading sebelum memulai pelajaran sejak tahun 2012 sebagai salah satu program yang mengajak peserta didik untuk meningkatkan pemahaman dalam pelajaran. Dalam kegiatan silent reading SMK YPM 3 Taman memberikan waktu selama 15 menit yang mewajibkan seluruh siswa membaca secara senyap sebelum memulai mata pelajaran. Dengan adanya program tersebut, diharapkan dapat meningkatkan kecerdasan kognitif peserta didik dalam mempelajari mata pelajaran Aqidah Akhlak. 
Sufinatin Aisida, Pengaruh Silent Reading Terhadap Peningkatan Kecerdasan Kognitif Peserta Didik

\section{Pembahasan}

\section{A. Pengertian silent reading, Tujuan dan Macamnya}

\section{Pengertian Silent Reading}

Kegiatan membaca dapat memberikan manfaat luar biasa bagi si pembaca, ia akan memiliki pengethuan baru serta wawasan baru dan menambah perbendaharaan pengalaman baru dengan mambaca. Menurut Munaf, dengan membaca dapat diketahui sejarah suatu bangsa, kejadian-kejadian atau peristiwaperistiwa waktu lampau, maupun waktu sekarang di tempat lain atau berbagai cerita yang menarik tentang masalah kehidupan di dunia ini. Budaya membaca sangat bermanfaat untuk memperdalam ilmu pengetahuan baik dari sekolah maupun dari luar sekolah, karena kita hanya dapat dari beberapa di sekolah sedangkan sisanya kita peroleh dari diri kita senidiri. Dengan budaya membaca sejak dini akan membuat kita tahu akan dunia diluar rumah kita tanpa harus keluar dari rumah. Membaca dipandang sebagai sutu kegiatan yang amat strategis dan mendasar dalam perkembangan psikologis setiap manusia. Hal ini dapat dibuktikan bahwa apa yang dibaca akan berpengaruh terhadap pola pikir dan perilakunya pada kehidupan sehari-hari. ${ }^{5}$

Gardiner menjelaskan Silent Reading, yaitu waktu membaca secara bersama- sama di kelas secara diam atau tenang selama waktu yang ditentukan yaitu 15 sampai 20 menit. $^{6}$

Tarigan menjelaskan bahwa, teknik membaca diam atau teknik membaca dalam hati merupakan teknik membaca tanpa suara dan sangat cocok untuk memahami sebuah tek bacaan. Membaca dalam hati diugnakan untuk menangkap pokok-pokok pikiran yang terkandung dalam bacaan, sementara secara umum digunakan untuk memperoleh informasi dengan cara berkonsentrasi fisik dan mental, membaca secepatnya, memahami isi, menghayati isi, dan

\footnotetext{
${ }^{5}$ Munaf, Y., Upaya Meningkatkan Minat Baca Siswa, Jurnal Pendidikan Bahasa Sastra dan Seni, 2002, $3(2): 241-250$

6 Gardiner, Steve, Bulding Student Literancy Throught Sustained silent Reading. UnitedStates of America: Association for Supervision and curriculum Development, 2005, hlm. 15
} 
Sufinatin Aisida, Pengaruh Silent Reading Terhadap Peningkatan Kecerdasan Kognitif Peserta Didik

mengungkapkan kembali isi bacaan. Tarigan menjelaskan 4 langkah teknik membaca dalam hati ini diantaranya adalah:1) guru menerangkan kata-kata yang dianggap sulit atau baru bagi siswa, alternatif guru untuk menghindari ketergantungan siswa adalah dengan membuat daftar kata-kat sulit atau kata-kata baru dan siswa dilatih untuk mempergunakan kamus untuk mencari kata-kata tersebut. 2). Guru memberi waktu 15 menit untuk membaca dalam hati suatu bacaan yang disajikan, sebaiknya bacaan yang berisi masalah baru, waktu disesuaikan dengan panjang pendeknya bacaan tersebut. 3) jika waktu yang disediakan sudah habis maska siswa disuruh untuk menutup buku bacaan tersebut, 4) guru memberikan pertanyaan mengenai bacaan baik berupa pertanyaan tentang bacaan atau tentang pikiran. Jawaban dapat pula secara tertulis untuk melatih kecermatan siswa dalam menulis. ${ }^{7}$

Ajaran Islam telah menjelaskan betapa pentingnya membaca bagi umat Islam, seperti wahyu yang pertama kali diturunkan kepada nabi Muhammad tentang membaca, yang terdapat di dalam al-Quran surat al-Alaq ayat 1-5:

Bacalah dengan nama Rabbmu yang telah menciptakan. Dia telah menciptakan manusia dari segumpal darah. Bacalah dan rabbmulah yang paling Pemurah.Yang mengajarkan manusia dengan perantara qalam. Dia mengajari manusia apa yang belum diketahuinya. (al Alaq: 1-5).

Menurut Harjasujana, membaca diam adalah kegiatan membaca tanpa mengeluarkan suara, bahkan lebih dari itu silent reading adalah membaca tanpa menggerakkan bibir, tanpa gerakan kepala, tanpa berbisik dan tanpa menggunakan alat tunjuk meskipun dengan jari telunjuk". ${ }^{8}$

Jadi dapat diambil sebuah kesimpulan bahsa membaca dalam hati atau disebut membaca senyap adalah penerapan suatu kegiatan yang dilakukan oleh suatu lembaga untuk membaca buku bacaan sebelum memulai pelajaran dengan durasi waktu 10 sampai dengan 15 menit.

\footnotetext{
${ }^{7}$ Tarigan, dkk, Membaca Sebagai Suatu Keterampilan Berbahasa, Bandung: Angakasa 1979, lihat pula Tarigan, Prinsip-prinsip Dasar Metode Riset Pengajaran dan Pembelajaran Bahasa, Bandung: 1993).

${ }^{8}$ Harjasujana, Membaca dalam Teori dan Praktik, (Bandung, Mutiara, 2003), hlm.126
} 
Sufinatin Aisida, Pengaruh Silent Reading Terhadap Peningkatan Kecerdasan Kognitif Peserta Didik

\section{Tujuan Program Silent Reading}

Menurut Tarigan Tujuan utama dalam membaca dalam hati adalah untuk mencari serta memperoleh informasi, mencakup isi, memahami makna bacaan. ${ }^{9}$ Sedangkan menurut Blanton dkk dan Irwin dalam Rarida dijelaskan:

1. Kesenangan

2. Menyempurnakan membaca nyaring

3. Menggunakan strategi tertentu

4. Memperbarui pengetahuannya tentang suatu topik

5. Mengaitkan informasi baru dengan informasi yang telah diketahuinya

6. Memperoleh informasi untuk pengetahuan lisan atau tertulis

7. Mengkonfirmasikan atau menolak prediksi

8. Menjawab pertanyaan-pertanyaan yang spesifik. ${ }^{10}$

Sedangakan menurut Dharma tujuan membaca senyap bagi peserta didik adalah:

1. Kesenangan

2. Menyempurnakan kemampuan membaca

3. Meningkatkan pemahaman

4. Memperoleh informasi

5. Menjawab pertanyaan-pertanyaan yang spesifik. ${ }^{11}$

Berdasarkan uraian di atas maka dapat ditarik kesimpulan bahwa tujuan utama kegiatan silent reading adalah untuk mencari informasi bacaan secara mendalam dan memahami bacaan. Selain itu kegiatan membaca senyap juga bertujuan untuk menjawab pertanyaan - pertanyaan yang spesifik. Membiasakan peserta didik untuk selalu membaca, dan dapat meningkatkan keterampilan membaca peserta didik.

\footnotetext{
${ }^{9}$ Tarigan, Prinsip-prinsip Dasar Metode Riset Pengajaran dan Pembelajaran Bahasa, hlm.9

10 Farida Rahim, Pengajaran Membaca di Sekolah Dasar, (Jakarta, Bumi Aksara, 2008). hlm.11-12.

${ }^{11}$ Dharma, hlm.21
} 
Sufinatin Aisida, Pengaruh Silent Reading Terhadap Peningkatan Kecerdasan Kognitif Peserta Didik

\section{Macam-macam Membaca Dalam Silent Reading}

Menurut Tarigan, silent reading terbagi menajdi dua, yaitu:

\section{a. Membaca ekstensif}

Membaca ekstensif berarti membaca secara luas. Objeknya meliputi sebanyak mungkin teks dalam waktu yang sesingkat mungkin. Kegiatan membaca ekstensif adalah untuk memahami isi yang peting - penting dengan cepat sehingga dengan demikian membaca secara efisien dapat terlaksana. Membaca ekstensif ini meliputi:

\section{1).Membaca survey}

Membaca guna menemukan informasi dengan cara memeriksa, melihat - lihat, dan meneliti terlebih dahulu apa yang akan kita telaah.

2). Membaca sekilas (skimming)

Membaca sekilas yaitu membaca yang membuat mata kita bergerak dengan cepat melihat, memperhatikan bahan tertulis untuk mencari serta mendapatkan informasi.

3). Membaca dangkal (superficial)

Membaca bahan bacaan secara dangkal dengan tujuan memperoleh pemahaman secara dangkal. Biasanya dilakukan ketika kita ingin membaca demi kesenangan, membaca bacaan ringan guna mendatangkan kebahagiaan di waktu senggang. Membaca ini tidak dapat menuntut keseriusan, pemahaman terhadap bacaan pun tidak begitu penting. Hal penting dalam membaca ini adalah untuk kesenangan.

\section{b. Membaca Intensif}

Membaca intensif adalah studi seksama, telaah, teliti, dan penanganan terperinci. Membaca intensif dibedakan atas: 
Sufinatin Aisida, Pengaruh Silent Reading Terhadap Peningkatan Kecerdasan Kognitif Peserta Didik

a. Membaca teliti

Proses membaca yang dilakukan dengan ketelitian yang tinggi guna menemukan informasi dalam bahan bacaan sesulit apapun bahan bacaan tersebut.

b. Membaca pemahaman

Sejenis membaca yang bertujuan untuk memahami tentang standar-standar atau norma - norma kesastraan, resensi kritis dan pola pola fiksi. Membaca pemahaman ini akan memberikan pemahaman yang baik terhadap pembaca, membaca jenis ini sangat baik jika diterapkan oleh seorang pembaca yang ingin untuk memahami bahan-bahan yang sulit.

c. Membaca kritis

Membaca kritis adalah membaca yang dilakukan secara bijaksana, mendalam, evaluatif, dengan tujuan untuk menemukan keseluruhan bahan bacaan.

d. Membaca ide Membaca ide adalah kegiatan membaca yang ingin mencari, memperoleh, serta memanfaatkan yang terdapat dalam bacaan.

e. Membaca kreatif

Membaca kreatif adalah membaca tidak lanjut dari membaca ide. Kelebihannya yaitu membaca secara kreatif mampu menerapkan hasil membacanya untuk kehidupan sehari-hari. ${ }^{12}$

\section{Keterampilan yang dituntut dalam silent reading}

Menurut Tarigan, silent reading merupakan suatu kegiatan yang menuntut aneka ragam keterampilan agar tujuan dapat tercapai.

1. Membaca tanpa bersuara, tanpa gerakan-gerakan bibir atau kepala, tanpa berbisik, dan tanpa menunjuk-nunjuk dengan jari

12 Tarigan, Prinsip-prinsip Dasar Metode Riset Pengajaran dan Pembelajaran Bahasa, hlm. 
Sufinatin Aisida, Pengaruh Silent Reading Terhadap Peningkatan Kecerdasan Kognitif Peserta Didik

2. Membaca lebih cepat secara dalam hati daripada bersuara

3. Memahami bahan yang dibaca secara diam

4. Menikmati bahan bacaan yang dibaca dalam hati

5. Senang membaca dalam hati

6. Dapat menyesuaikan kecepatan membaca dengan tingkat kesukaran yang terdapat dalam buku

7. Dapat membaca 180 patah kata dalam satu menit pada bacaan. ${ }^{13}$

\section{B. Tingkat Kecerdasan Kognitif Peserta Didik}

\section{Pengertian tingkat kecerdasan kognitif}

Menurut Kamus Umum Bahasa Indonesia peningkatan adalah proses, cara, perbuatan meningkatkan (usaha, kegiatan, dan sebagainya). Sedangkan Sedangkan cerdas adalah kesempurnaan perkembangan akal budi. ${ }^{14}$

Sedangkan pengertian kecerdasan kognitif menurut Ali "Intelek/ kognitif adalah akal budi atau intelegensi yang berarti kemampuan untuk meletakkan hubungan dari proses berfikir". ${ }^{15}$ Menurut Susanto, kecerdasan kognitif adalah suatu proses berpikir, yaitu kemampuan individu untuk menghubungkan, menilai, dan mempertimbangkan suatu kejadian atau peristiwa. ${ }^{16}$

Sedangkan menurut Syah, ada 6 indikator yang dapat dikembangkan dalam tingkatan kecerdasan kognitif peserta didik. ${ }^{17}$ kategori dan indikatornya ditunjukkan seperti pada tabel 1, dibawah ini:

\footnotetext{
${ }^{13}$ Tarigan, hlm.38

${ }^{14}$ Kementerian Pendidikan dan Kebudayaan Republik Indonesia, 1989, hlm.51

${ }^{15}$ Tarigan, Prinsip-prinsip Dasar Metode Riset Pengajaran dan Pembelajaran Bahasa, hlm.

${ }^{16}$ Susanto, Perkembangan Anak Usia Dini, (Jakarta, Kencana Prenada: 2011), hlm.48

${ }^{17}$ Syah, Psikologi Pendidikan, (Bandung:PT. Remaja Rosdakarya, 2014). hlm.148
} 48 
Sufinatin Aisida, Pengaruh Silent Reading Terhadap Peningkatan Kecerdasan Kognitif Peserta Didik

Tabel 1, kategori dan indikator kecerdasan kognitif

\begin{tabular}{|c|c|}
\hline Kategori kecerdasan kognitif & Indikator \\
\hline 1. Pengamatan & $\begin{array}{l}\text { 1. Dapat menunjukkan } \\
\text { 2. Dapat membangdingkan } \\
\text { 3. Dapat menghubungkan }\end{array}$ \\
\hline 2. Ingatan & $\begin{array}{l}\text { 1. Dapat menyebutkan } \\
\text { 2. Dapat menunjukkan kembali }\end{array}$ \\
\hline 3. Pemahaman & $\begin{array}{l}\text { 1. Dapat menjelaskan } \\
\text { 2. Dapat mendefinisikan dengan lisan } \\
\text { sendiri }\end{array}$ \\
\hline 4. Penerapan & $\begin{array}{l}\text { 1. Dapat memberikan contoh } \\
\text { 2. Dapat menggunakan secara tepat }\end{array}$ \\
\hline $\begin{array}{l}\text { 5. Analisis (pemeriksaan dan } \\
\text { pemilahan secara teliti) }\end{array}$ & $\begin{array}{l}\text { 1. Dapat menguraikan } \\
\text { 2. Dapat mengklasifikasikan }\end{array}$ \\
\hline $\begin{array}{l}\text { 6. Sintesis (membuat paduan baru } \\
\text { dan utuh) }\end{array}$ & $\begin{array}{l}\text { 1. Dapat menghubungkan } \\
\text { 2. Dapat menyimpulkan } \\
\text { 3. Dapat menggeneralisasikan }\end{array}$ \\
\hline
\end{tabular}

Berdasarkan pemaparan diatas, tingkat kecerdasan kognitif adalah suatu kegiatan yang dilakukan untuk meningkatkan kemampuan berfikir, kemampuan menilai, dan kemampuan mempertimbangkan peserta didik terhadap suatu materi mata pelajaran. 
Sufinatin Aisida, Pengaruh Silent Reading Terhadap Peningkatan Kecerdasan Kognitif Peserta Didik

\section{Tahapan Perkembangan Intelek/Kognitif}

Jean Piaget dalam Ali, ${ }^{18}$ membagi perkembangan intelek/kognitif menjadi empat tahapan sebagai berikut.

1. Tahap Sensori-Motoris

Tahap ini dialami pada usia 0-2 tahun. Pada tahap ini, anak berada dalam suatu masa pertumbuhan yang ditandai oleh kecenderungan-kecenderungan sensori-motoris yang sangat jelas. Segala perbuatan merupakan perwujudan dari proses pematangan aspek sensori-motoris tersebut. Pada tahap ini interaksi anak dengan lingkungannya, termasuk orang tuanya, terutama dilakukan melalui perasaan dan otot-ototnya. Interaksi ini terutama diarahkan oleh sensasi-sensasi dari lingkungannya. Dalam melakukan interaksi dengan lingkunnya, termasuk juga dengan orang tuanya, anak mengembangkan kemampuannya untuk mempersepsi, melakukan sentuhan-sentuhan, melakukan berbagai gerakan, dan secara perlahan-lahan belajar mengoordinasikan tindakan-tindakannya.

2. Tahap Praoperasional

Tahap ini berlangsung pada usia 2-7 tahun. Tahap ini disebut juga tahap intuisi sebab perkembangan kognitifnya memperlihatkan kecenderungan yang ditandai oleh suasana intuitif. Artinya, semua perbuatan rasionalnya tidak didukung oleh pemikiran tetapi oleh unsur perasaan, kecenderungan alamiah, sikap-sikap yang diperoleh dari orang-orang bermakna, dan lingkungan sekitarnya. Pada tahap ini, anak sangat bersifat egosentris sehingga seringkali mengalami masalah dalam berinteraksi dengan lingkungannya, termasuk dengan orang tuanya. Dalam berinteraksi dengan orang lain, anak cenderung sulit untuk dapat memahami pandangan orang lain dan lebih banyak mengutamakan pandangannya sendiri. Dalam berinteraksi dengan lingkungannya, ia masih sulit untuk membaca kesempatan atau kemungkinan-kemungkinan karena masih

\footnotetext{
${ }^{18}$ Mohammad Ali, Psikologi Remaja. (Jakarta: PT. Bumi Aksara. 2010), hlm.26
} 
Sufinatin Aisida, Pengaruh Silent Reading Terhadap Peningkatan Kecerdasan Kognitif Peserta Didik

punya anggapan bahwa hanya ada satu kebenaran atau peristiwa dalam setiap siatuasi.

Pada tahap ini, anak tidak selalu ditentukan oleh pengamatan indrawi saja, tetapi juga pada intuisi. Anak mampu menyimpan kata-kata serta menggunakannya, terutama yang berhubungan erat dengan kebutuhan mereka. Pada masa ini anak siap untuk belajar bahasa, membaca, dan menyanyi. Ketika kita menggunakan bahasa yang benar untuk berbicara pada anak, akan mempunyai akibat sangat baik pada perkembangan bahasa mereka. Cara belajar yang memegang peran pada tahap ini ialah intuisi. Intuisi membebaskan mereka dari berbicara semaunya tanpa menghiraukan pengalaman konkret dan paksaan dari luar. Sering kita lihat anak berbicara sendiri dengan benda-benda yang ada disekitarnya, misalnya pohon, anjing, kucing, dan sebagainya, yang menurut mereka benda-benda tersebut dapat mendengar dan berbicara. Peristiwa semacam ini baik untuk melatih diri anak menggunakan kekayaan bahasanya bahasanya. Piaget menyebut tahap ini sebagai collective monologue, pembicara yang egosentris dan sedikit hubungan dengan orang lain.

3. Tahap Operasional Konkret

Tahap ini berlangsung antara usia 7-11 tahun. Pada tahap ini, anak mulai menyesuaikan diri dengan realitas konkret dan sudah mulai berkembang rasa ingin tahunya. Pada tahap ini, interaksinya dengan lingkungan, termasuk dengan orang tuanya, sudah semakin berkembang dengan baik karena egosentrisnya sudah semakin berkurang. Anak sudah dapat mengamati, menimbang, mengevaluasi, dan menjelaskan pikiran-pikiran orang lain dalam cara-cara yang kurang egonsentris dan lebih objektif.

4. Tahap Operasional Formal

Tahap ini dialami oleh anak pada usia 11 tahun ke atas. Pada masa ini, anak telah mampu mewujudkan suatu keseluruhan dalam pekerjaannya yang merupakan hasil dari berpikir logis. Aspek perasaan dan moralnya juga telah berkembang sehingga dapat mendukung penyelesaian tugas-tugasnya. 
Sufinatin Aisida, Pengaruh Silent Reading Terhadap Peningkatan Kecerdasan Kognitif Peserta Didik

Pada tahap ini, interaksinya dengan lingkungan sudah amat luas, menjangkau banyak teman sebayanya dan bahkan berusaha untuk dapat berinteraksi dengan orang dewasa. Kondisi seperti ini tidak jarang menimbulkan masalah dalam interaksinya dengan orang tua. Namun, sebenarnya secara diamdiam mereka juga masih mengharapkan perlindungan dari orang tua karena belum sepenuhnya mampu memenuhi kebutuhan dirinya sendiri. Jadi, pada tahap ini ada semacam tarik-menarik antara ingin bebas dengan ingin dilindungi.

\section{Faktor-faktor yang mempengaruhi perkembangan intelek/ kognitif}

Menurut Ali, faktor yang memengaruhi perkembangan intelek individu ini terjadi perbedaan pendapat di antara para penganut psikologi. Kelompok psikometrika radikal berpendapat bahwa perkembangan intelektual individu sekitar 90\% saja. Kelompok inimemberikan bukti bahwa individu yang memiliki hereditas intelektual unggul, pengembangannya sangat mudah meskipun dengan intervensi lingkungan yang tidak maksimal. Adapun individu yang memiliki hereditas intelektual rendah seringkali intervensi lingkungan sulit dilakukan meskipun sudah secara maksimal. ${ }^{19}$

Sebaliknya, kelompok penganut pedagogis radikal amat yakin bahwa intervensi lingkungan, termasuk pendidikan, justru memiliki andil sekitar 80-85\%, sedangkan hereditas hanya memberikan kontribusi $15-20 \%$ terhadap perkembangan intelektual individu. Syaratnya adalah memberikan kesempatan rentang waktu yang cukup bagi individu untuk mengembangkan intelektualnya secara maksimal.

Tanpa mempertentangkan kedua kelompok radikal itu, perkembangan intelektual sebenarnya dipengaruhi oleh dua faktor utama, yaitu hereditas dan lingkungan. Pengaruh kedua faktor itu pada kenyataannya tidak terpisah secara sendiri-sendiri melainkan seringkali merupakan resultan dari interaksi keduanya.

\footnotetext{
${ }^{19}$ Mohammad Ali, hlm.33.
} 
Sufinatin Aisida, Pengaruh Silent Reading Terhadap Peningkatan Kecerdasan Kognitif Peserta Didik

Pengaruh faktor hereditas dan lingkungan terhadap perkembangan intelektual itu dapat dijelaskan berikut ini:

\section{Faktor Hereditas}

Semenjak dalam kadungan, anak telah memiliki sifat-sifat yang menentukan daya kerja intelektualnya. Secara potensi anak telah membawa kemungkinan, apakah akan menjadi kemampuan berpikir setaraf normal, di atas normal, atau di bawah normal. Namun, potensi ini tidak akan berkembang atau terwujud secara optimal apabila lingkungan tidak memberi kesempatan untuk berkembang. Oleh karena itu, pernanan lingkungan sangat menentukan perkembangan intelektual anak.

2. Faktor Lingkungan

Ada dua lungkungan yang sangat penting peranannya dalam memengaruhi perkembangan intelek anak, yaitu keluarga dan sekolah.

a) Keluarga

Intervensi yang paling penting dilakukan oleh keluarga atau orang tua adalah memberikan pengalaman kepada anak dalam berbagai bidang kehidupan sehingga anak memiliki informasi yang banyak yang merupakan alat bagi anak untuk berpikir. Cara-cara yang digunakan, misalnya memberi kesempatan kepada anak untuk merealisasikan ide-idenya, menghargai ide-ide tersebut, memuaskan dorongan keingintahuan anak dengan jalan seperti menyediakan bacaan, alat-alat keterampilan, dan alat-alat yang dapat mengembangkan daya kreativitas anak. Memberi kesempatan atau pengalaman tersbut akan menuntut perhatian orang tua.

b) Sekolah

Sekolah adalah lembaga formal yang diberi tanggung jawab untuk meningkatkan perkembangan anak termasuk perkembangan berpikir anak. Dalam hal ini, guru hendaknya menyadari bahwa perkembangan intelektual anak terletak di tangannya. Beberapa cara di antaranya adalah sebagai berikut. 
Sufinatin Aisida, Pengaruh Silent Reading Terhadap Peningkatan Kecerdasan Kognitif Peserta Didik

1) Menciptakan interaksi atau hubungan yang akrab dengan peserta didik. Dengan hubungan yang akrab tersebut, secara psikologis peserta didik akan merasa aman sehingga segala masalah yang dialaminya secara bebas dapat dikonsultasikan dengan guru mereka.

2) Memberi kesempatan kepada para peserta didik untuk berdialog dengan orang-orang yang ahli dan berpengalaman dalam berbagai bidang ilmu pengetahuan, sangat menunjang perkembangan intelektual anak. Membawa para peserta didik ke objek-objek tertentu, seperti objek budaya dan ilmu pengetahuan, sangat menunjang perkembangan intelektual peserta didik.

3) Menjaga dan meningkatkan pertumbuhan fisik anak, baik melalui kegiatan olahraga maupun menyediakan gizi yang cukup, sangat penting bagi perkembangan berpikir peserta didik. Sebab jika peserta didik terganggu secara fisik, perkembangan intelektualnya juga akan terganggu.

4) Meningkatkan kemampuan berbahasa peserta didik, baik melalui media cetak maupun dengan menyediakan situasi yang memungkinkan para peserta didik berpendapat atau mengemukakan ide-idenya. Hal ini sangat besar pengaruhnya bagi perkembangan intelektual peserta didik.

\section{Mata Pelajaran Aqidah Akhlak}

\section{Pengertian Mata Pelajaran Aqidah Akhlak}

Secara etimologi (bahasa) akidah berasal ari kata "aqadah ya'qidu-aqdan" berarti ikatan perjanjian, sangkuran yang kokoh. ${ }^{20}$

Sedangkan Alim, menjelaskan bahwa Akidah secara etimologis berarti yang terikat. Setelah terbentuk menjadi kata, aqidah berarti perjanjian yang teguh dan kuat, terpatri da tertanam di dalam lubuk hati yang paling dalam. Secara terminologis berarti credo,creed, keyakinan hidup iman dalam arti khas, yakni pengikraran yang bertolak dari hati. Dengan demikian aqidah adalah urusan yang

\footnotetext{
${ }^{20}$ Yunus, Kamus Arab-Indonesia, (Jakarta, Hidakarya Agung: 1972), hlm.247.
} 
Sufinatin Aisida, Pengaruh Silent Reading Terhadap Peningkatan Kecerdasan Kognitif Peserta Didik

wajib diyakini kebenarannya oleh hati, menentramkan jiwa, dan menjadi keyakinan yang tidak bercampur dengan keraguan. ${ }^{21}$

Menurut Nata menjelaskan akata akhlak berasal dari bahasa arab, khilqun yang berarti kejadian, perangai, tabiat, atau karakter. Sedangkan menurut istilah akhlak adalah sifat yang melekat pada diri seseorang dan menjadi identitasnya. Selain itu, akhlak juga dapat pula diartikan sebagai sifat yang telah dibiasakan, ditabiatkan sehingga menjadi kebiasaan dan mudah dilaksanakan, serta dapat dirasakan manfaatnya. ${ }^{22}$

Berdasarkan pengertian di atas dapat ditarik sebuah kesimpulan bahwa akidah akhlak upaya sadar dan terencana dalam menyapkan peserta didik agar dapat mengenal,memahami, menghayati dan mengimani Allah serta dapat merealisasikannya dalam kehiduapn sehari-hari melalui kegiatan bimbingan, pengajaran, latihan maupun pembiasaan.

\section{Tujuan Mata Pelajaran Aqidah Akhlak}

Menurut Al-Abrasyi ada beberapa tujuan dari mata pelajaran aqidah akhlak bertujuan untuk:

1) Senantiasa membersihkan diri dari sifat-sifat yang tercela

2) Senantiasa memiliki niat yang mulia

3) Meninggalkan kesibukan duniawi

4) Menjalin hubungan yang harmonis dengan para guru

5) Menunjukkan sikap sopan dan santun kepada guru

6) Tekun dan bersungguh - sungguh dalam belajar

7) Memelihara rasa persaudaraan dan persahabatan. ${ }^{23}$

${ }^{21}$ Alim, ,Psikologi Remaja dan Perkembangan Peserta didik, (Jakarta, Bumi Aksara 2011), hlm. 124

${ }^{22}$ Nata, Kapita Selekta Pendidikan Islam: Isu-isu Kontemporer Pendidikan Islam, (Bandung: Rajawali Pers, 2013),hlm. 208.

${ }^{23}$ Al-Abrasy, Dasar-Dasar Pokok Pendidikan Islam, (Jakarta: Alfabeta, 1978), hlm. 140 
Sufinatin Aisida, Pengaruh Silent Reading Terhadap Peningkatan Kecerdasan Kognitif Peserta Didik

\section{Ruang Lingkup Mata Pelajaran Aqidah Akhlak}

Menurut Peraturan Menteri Agama Republik Indonesia Nomor 2 tahun 2008 tentang Standar Kompetensi Lulusan dan Standar isi Pendidikan Agama Islam dan Bahasa Arab di Madrasah, ruang lingkup mata pelajaran Aqidah Akhlak, meliputi:

1) Aspek Aqidah, meliputi:

a) Prinsip - prinsip aqidah dan metode peningkatannya

b) Asma'ul Husna

c) Macam - macam tauhid

d) Syirik dan implikasinya dalam kehidupan

e) Pengertian dan fungsi ilmu kalam serta hubungannya

f) Aliran - aliran ilmu kalam

2) Aspek Akhlak, meliputi:

1) Pengertian Akhlak

2) Induk - induk akhlak terpuji dan tercela

3) Metode peningkatan kualitas akhlak

4) Macam - macam akhlak terpuji

5) Akhlak terpuji dalam pergaulan remaja

6) Tasawuf

\section{E. Faktor Pendukung dan Penghambat Silent reading}

\section{Faktor Pendukung Silent reading}

Menurut Mukti Harahap ${ }^{24}$ faktor pendukung program membaca senyap adalah:

1) Sarana dan Prasarana

Adanya sarana untuk mensosialisasikan kebijakan atau program dari sekolah. Sarana itu berupa rapat kerja guru, rapat manajemen, pertemuan orang tua,

${ }^{24}$ Al-Abrasy, hlm. 126 
Sufinatin Aisida, Pengaruh Silent Reading Terhadap Peningkatan Kecerdasan Kognitif Peserta Didik

dan masih banyak sarana yang lain untuk menyampaikan kebijakan yang dirancang. Adanya pokok baca, mading, perpustakaan merupakan penerapan prinsip kegiatan membaca dilakukan kapan pun dan dimanapun. Siswa dengan mudah mengakses buku sebagai sumber ilmu.

2) Bahan bacaan

Adanya hibah buku atau sumbangan buku dari orang tua. Program ini menjadi faktor pendukung untuk ketersediaan sumber literasi untuk membaca.

3) Dukungan orang tua

Dukungan dari orang tua disampaikan melalui surat ke orang tua yang dititipkan melalui anak-anak dalam bentuk surat edaran program gerakan membaca senyap di sekolah.

4) Adanya alokasi waktu dan dana untuk menunjang kecapakan membaca siswa

5) Guru-guru mempunyai semangat belajar yang baik.

\section{Faktor Penghambat Silent reading}

Setiap tujuan pasti memiliki hambatan. Demikian pula dengan kegiatan silent reading seperti yang diungkapkan oleh Aulia Akbar ${ }^{25}$ hambatan-hambatan dalam silent reading diantaranya adalah:

1) Kebiasan program silent reading di sekolah yang belum menjadi prioritas

Baik disekolah maupun di rumah belum menyadari arti pentingnya membaca. Kegiatan membaca hanya menjadi kegiatan penyelesaian akademik dan tugas semata. Membaca masih didasari sikap paksaan pemenuhan kewajiban, bukan sebagai sarana hiburan dan kebutuhan. Aktivitas ini berbeda dengan negara maju, dimana membaca merupakan kebutuhan primer yang harus dipenuhi.

25 Aulia Akbar. Jurnal Membudayakan Literasi dengan Program 6M di Sekolah dasar. Dharma, 2017), hlm. 47 
Sufinatin Aisida, Pengaruh Silent Reading Terhadap Peningkatan Kecerdasan Kognitif Peserta Didik

2) Kurangnya buku bacaan/bahan bacaan

Salah satu kelemahan dalam menerapkan program silent reading adalah kurang tersedianya bahan bacaan. Belum beragamnya karya tulis mengakibatkan menurunya minat membaca siswa.

3) Lingkungan tidak mendukung

Tidak ada contoh yang baik serta tidak ada dorongan dari lingkungan sekitar membuat siswa tidak merasa perlu untuk membaca. Lingkungan yang apriori terhadap kebiasaan membaca menjadi faktor siswa enggan untuk membaca.

4) Merupakan kegiatan yang memerlukan konsentrasi. Pada praktiknya membaca adalah aktivitas yang tidak bisa dilakukan dengan kegiatan lain. Diperlukan perhatian dan fokus agar dapat menangkap dan memahami isi bacaan.

\section{Hasil Pembahasan Penelitian}

Hasil penelitian tentang pengaruh silent reading terhadap kecerdasan kognitif peserta didik, menunjukkan hasil bahwa 1). Terdapat tingkat usaha yang tinggi dari guru mata pelajaran aqidah akhlak dalam menggunakan waktu, menyediakan fasilitas, memperhatikan ketertiban, dan memberikan evaluasi serta solusi pelaksanaan program silent reading yang diharapkan siswa mampu menguasai materi pelajaran yang diberikan. Adapun kategori menunjukkan cukup baik karena berada direntan $56 \%$ - 75\% hal ini berdasarkan hasil prosentase dengan nilai 71\%. 2). Penelitian Tingkat kecerdasan kognitif peserta didik Hasil penelitian menunjukkan bahwa adanya ketertiban dari peserta didik sehingga peserta didik mampu berfikir, menilai, menyebutkan, menjelaskan dan memberikan contoh pada suatu materi pelajaran. Adapun kategori menunjukkan cukup baik karena berdasarkan standar yang telah penulis tetapkan berada direntan 56\% - 75\% hal ini berdasarkan hasil prosentase dengan nilai 68\%. 3) Pengaruh silent reading terhadap tingkat kecerdasan kognitif peserta didik pada mata pelajaran aqidah akhlak memberikan pengaruh yang cukup karena berada di antara $0,41-0,70$ yaitu 0,585 . Dengan nilai koefisien diterminasi 0,343 yang 
Sufinatin Aisida, Pengaruh Silent Reading Terhadap Peningkatan Kecerdasan Kognitif Peserta Didik

menujukkan bahwa silent reading memberikan pengaruh 34,3\% terhadap tingkat kecerdasan kognitif peserta didik pada mata pelajaran aqidah akhlak.

\section{Kesimpulan}

Berdasarkan hasil penelitian yang berjudul pengaruh silent reading terrhadap tingkat kecerdasan kognitif peserta didik di SMK YPM 3 Taman Sidoarjo yang telah penulis lakukan, maka dapat diambil kesimpulan bahwa:

1. Pelaksanaan silent reading di SMK YPM 3 Taman Sidoarjo dinyatakan cukup baik, karena berada direntan $56 \%$ - 75\% hal ini berdasarkan hasil prosentase dengan nilai $71 \%$

2. Tingkat kecerdasan kognitif peserta didik di SMK YPM 3 Taman Sidoarjo berada direntan 56\% - 75\% hal ini berdasarkan hasil prosentase dengan nilai 68\%. Yang dinyatakan cukup baik.

3. Silent reading memberikan pengaruh $34,3 \%$ terhadap tingkat kecerdasan kognitif peserta didik pada mata pelajaran aqidah akhlak, dalam hal ini berarti $34,3 \%$ peserta didik mampu berfikir, menilai, menyebutkan, menjelaskan dan memberikan contoh pada suatu materi pelajaran, dan 65,7\% dipengaruhi oleh faktor lain yang belum diteliti oleh peneliti.

\section{Daftar Pusataka}

Al-Abrasy, 1978, Dasar-Dasar Pokok Pendidikan Islam

Ali, Mohammad. 2010. Psikologi Remaja. Jakarta: PT. Bumi Aksara. Alim,

Alim, 2011,Psikologi Remaja dan Perkembangan Peserta didik, Jakarta, Bumi Aksara

Angkasa Trelease, 2017. The Read-Aloud Handbook. Jakarta: PT. Mizan Publika 
Sufinatin Aisida, Pengaruh Silent Reading Terhadap Peningkatan Kecerdasan Kognitif Peserta Didik

Aulia Akbar. 2017, Jurnal Membudayakan Literasi dengan Program 6M di Sekolah dasar. Dharma

Aulia Akbar. Jurnal Membudayakan Literasi dengan Program 6M di Sekolah dasar. Dharma,

Gardiner, Steve, 2005, Bulding Student Literancy Throught Sustained silent Reading. UnitedStates of America: Association for Supervision and curriculum Development

Gerakan Literasi Sekolah. Nata, Abuddin. 2013. Pemikiran Pendidikan Islam dan Barat.

M. Yunus, 1972, Kamus Arab-Indonesia, Jakarta, Hidakarya Agung.

Muhammad. 2011. Upaya Pembentukan Kepribadian Muslim. Bandung:PT Remaja Rosdakarya.

Munaf, Y. 2002, Upaya Meningkatkan Minat Baca Siswa, Jurnal Pendidikan Bahasa Sastra dan Seni, 3 (2):241-250

Rahim, Farida. 2008. Pengajaran Membaca di Sekolah Dasar. Jakarta: Bumi Aksara. Sudjana.

Sugiartini, 2010, Membaca Gaya Hidup dan Kapitalisme.

Susanto, 2011, Perkembangan Anak Usia Dini, Jakarta, Kencana Prenada,

Syah, 2014, Psikologi Pendidikan, Bandung:PT. Remaja Rosdakarya.

Tarigan, Henry Guntur. 2008. Membaca sebagai Suatu Keterampilan Berbahasa. Bandung.

Tilaar, H.A.R., 2002, Perubahan dan Pendidikan Pengantar Pedagogik Transformasi Untuk Indonesia, Jakarta, Pt. Grasindo

UU RI, Nomor 20 Pasal 4 ayat 5 tahun 2003 tentang Sistem Pendidikan Nasional 